\title{
THE POPULATION DYNAMICS OF INSECTS IN SUGARCANE FIELD AT AUNDIPATTI, THENI DISTRICT, TAMIL NADU.
}

\author{
Dr. Mrs. L. Merlin Dayana. ${ }^{1 *}$, \\ ${ }^{* 1}$ Assistant Professor in Zoology, J.A. College for Women, (Autonomous), Periyakulam.
}

\section{*Corresponding Author: -}

\begin{abstract}
: -
Sugarcane (Saccharum offecinarum L) is one of the most important commercial crops of the tropical countries and is the main source of sugar in the world. Sugarcane crop is affected by more than 60 insects of which about 10 insects are rather more important as far as the yield loss is concerned. Among the major insects damaging sugarcane, borers, sucking pests, soil dwelling insects are more prevalent in Tamil Nadu and adjoining states which account for $20 \%$ loss in cane yield and $15 \%$ loss in sugar yield. About 200 species of insects have been reported as damaging sugarcane crop in India. Light trap serves as an important survey tool to sample population of nocturnal insects effectively. Trapping methods are principal tools in insect pest management programs. The goal of this study was to assess population dynamics of insects in a sugarcane field at Aundipatti, Tamil Nadu. A 6-month study was conducted to sample insects using light trap at the farmer's field from July 2011 to December 2011. Collected specimens were identified to species level and predominant species were identified. Predominant herbivore species were Diatraea saccharalis, Melanotus communis and Agrostis capillaries L. The result of this study provides important information related to the status of insects in sugarcane field.
\end{abstract}

Key words: Population dynamics of insects, sugarcane, Predominant pest.

\section{(우 $($ (1)}




\section{INTRODUCTION}

Saccharum officinarum is the original sugarcane species. It is supposed to have originated in the Indonesian Archipelago. The species does not occur wild in nature but was grown and maintained for a long time by the natives of these islands. Later on it came to be cultivated in south India. Sugarcane plant during their different growth stages are attacked by a number of insect which are major constraints in getting higher yield (Aonnymous, 2006; Iqbal et al. 2012). Due to heavy infestation of the pests, serious decline $(86.00 \%$ reduction in cane yield;

$1.4-1.8 \%$ reduction in sugar recovery) in production has been reported by (Anonymous, 2006). Sugarcane is known to be attacked by about 200 species of insect and non-insect pests in India (David and Ananthanarayana, 1988). However, none of these pests warranted except at few locations, but now a day's sugarcane woolly aphid, Ceratovacuna lanigera (Zehntner) has appeared in pestiferous form with alarming speed of spread and severity has created panic among the farmers and threatened the sugar industry.

\section{Climate}

Sugarcane is grown in the world from a latitude $36.7^{\circ} \mathrm{N}$ to $31.0^{\circ} \mathrm{S}$, from sea level to $1000 \mathrm{~m}$ of altitude or a little more. It is considered as essentially a tropical plant. It is a long cycle.

\section{Rainfall}

A total rainfall between 1100 and $1500 \mathrm{~mm}$ is adequate provided the distribution is right, abundant in the months of vegetative growth followed by a dry period for ripening. During the active growth period rainfall encourages rapid cane growth, cane elongation and internode formation.

\section{Temperature}

Growth is closely related to temperature. Optimum temperature for sprouting (germination) of stem cuttings is $32^{\circ}$ to $38^{\circ} \mathrm{C}$. It slows down below $25^{\circ}$, reaches plateau between $30^{\circ}-34^{\circ}$, is reduced above $35^{\circ}$ and practically stops when the temperature is above $38^{\circ}$. Temperatures above $38^{\circ}$ reduce the rate of photosynthesis and increase respiration.

\section{Relative humidity}

High humidity (80-85\%) favors rapid cane elongation during grand growth period. A moderate value of $45-65 \%$ coupled with limited water supply is favorable during the ripening phase.

\section{Insects of sugarcane}

Sugarcane crop is affected by more than 60 insects of which about 10 insects are rather more important as far as the yield loss is concerned. Among the major insects damaging sugarcane, borers, sucking pests, soil dwelling insects are more prevalent in Tamil Nadu and adjoining states which account for $20 \%$ loss in cane yield and $15 \%$ loss in sugar yield. The population dynamics and biomass production of above ground insects in tropical grassland was recorded by Kaushal and Vats, 1983. Studies of insect population dynamics based on field observation and evaluation were carried out to understand the insect species interaction in any ecosystem. Ambrose and Livingstone (1989) studied the population dynamics of assassin bugs from peninsular India. Nader Sallam (2011) reported the review of current knowledge on the population dynamics of Dermolepida albohirtum (Waterhouse) (Coleoptera: Scarabaeidae).

\section{Studies on light trap collections}

Light trap serves as an important survey tool to sample population of nocturnal insects effectively. Trapping methods are principal tools in insect pest management programs. The different colour sticky traps are used to monitor leafhopper species on many crops (Kersting etal., 1997; Chu et al., 2000; Lessio and Alma, 2004; Raja and Arivudainambi, 2004). Ramamurthy et al. (2010) studied the different numbers of insects species caught by light traps with different light sources. Light trap catch is influenced not only by the actual population of adult insects present in the environment but also by weather factors and moonlight. Verma et al., (1982) thoroughly analysed the effect of temperature, relative humidity and rainfall on light trap catches for three years and indicated that rains only have a short lived but significant effect on trap catches.

\section{MATERIALS AND METHODS \\ Location of the study area}

Aundipatti, was selected for the study of population dynamics of insects associated with sugarcane field. The collection was done in the farmer's field

\section{Soil and crop}

Sugarcane is cultivated once in a Year. Soil is a medium for plant growth. It provides nutrients, water and anchorage to the growing plants. Maintenance of proper physical, chemical and biological conditions of the soil is necessary for realizing higher growth, yield and quality of sugarcane.

\section{Climate}

The climate in general is hot in summer and cool in winter. The bulk of rainfall is mainly due to North - East (October to December) monsoon and South - West (June to August) monsoon. 


\section{Light trap}

The light trap consisted of a metal funnel with a central light source of $100 \mathrm{~W}$ mercury lamp. At a bottom of a funnel a jar containing killing agent of formalin could be placed. The light trap is $50 \mathrm{~cm}$ or $0.5 \mathrm{~m}$ in diameter and $1 \mathrm{~m}$ height. The light trap was set on near the sugarcane field. The light trap was run once in fifteen days for a period of 3 months (July 2011 to December 2011). The light trap was regularly switched on at 18:00hrs (evening) and switched off at 6:00hrs (in the next morning). The light attracted insects passed through the funnel and got into the killer jar. The trap catches were removed soon after the light was switched off and sorted out on the same way. The collected entomofauna was counted individually (less abundant species and more abundant species). The insects thus collected from the two sites pooled together, identified and population status were carried out.

\section{Identification of insect species}

The collected specimens were stored in vials containing formalin solution and identified to species level. The specimens were identified with the help of related taxonomic materials. The specimens for each and every collection day were treated separately and were put into vials for biodiversity count.

\section{Statistical analysis}

\section{Correlation coefficient:}

Correlation coefficient was calculated using standard formula. The statistical treatment was given between different abiotic characters (temperature and rainfall). The correlation between monthly individuals of different orders and abiotic factors in total collection and light trap collection for 6 months in sugarcane field at Aundipatti.

\section{Karl Pearson's coefficient of correlation:}

Karl Pearson's, a great biometrician and statistician, suggested a mathematical method for measuring the magnitude of linear relationship between two variables. Karl Pearson's method is the most widely used method in practice and is known as Pearson coefficient of correlation. It is denoted by the symbol ' $\gamma$ '. The simplest formula is

$$
\gamma=\frac{\sum \mathrm{dxdy}}{\sqrt{\sum \mathrm{dx}^{2} \mathrm{Xdy^{2 }}}}=\frac{\sum(\mathrm{dx}) \mathrm{X}(\mathrm{dy})}{\sqrt{\sum\left(\mathrm{dx}^{2}\right) \mathrm{X}\left(\mathrm{dy}^{2}\right)}}
$$

Meteorological parameters of the study area

\begin{tabular}{|c|c|c|c|}
\hline Month & $\begin{array}{c}\text { Max. Tem } \\
\left({ }^{\mathbf{o}} \mathbf{C}\right)\end{array}$ & $\begin{array}{c}\text { Min. Tem } \\
\left({ }^{\mathbf{}} \mathbf{C}\right)\end{array}$ & $\begin{array}{c}\text { Total rainfall } \\
(\mathbf{m m})\end{array}$ \\
\hline July & 30.6 & 28.9 & 3.6 \\
\hline August & 30.1 & 28.5 & 34.0 \\
\hline September & 32.7 & 29.2 & 9.6 \\
\hline October & 37.9 & 25.6 & 241.1 \\
\hline November & 30.3 & 23.7 & 189.2 \\
\hline December & 27.8 & 25.8 & 32.2 \\
\hline
\end{tabular}

Month wise insect population of sugarcane field at Aundipatti

\begin{tabular}{|c|c|c|c|c|c|c|c|c|}
\hline Orders & July & August & September & October & November & December & Total & $\begin{array}{c}\text { Percentage } \\
(\%)\end{array}$ \\
\hline Coleoptera & 98 & 38 & 12 & 18 & 73 & 108 & 347 & 11.05 \\
\hline Diptera & 440 & 155 & 128 & 150 & 178 & 320 & 1371 & 43.69 \\
\hline Hemiptera & 52 & 48 & 55 & 0 & 14 & 0 & 169 & 5.38 \\
\hline Hymenoptera & 23 & 92 & 29 & 25 & 16 & 14 & 199 & 6.34 \\
\hline Lepidoptera & 4 & 20 & 42 & 73 & 142 & 153 & 434 & 13.83 \\
\hline Odonata & 21 & 13 & 65 & 41 & 71 & 67 & 278 & 8.85 \\
\hline Orthoptera & 58 & 47 & 42 & 29 & 29 & 135 & 340 & 10.83 \\
\hline Total & & & & & & & 3138 & \\
\hline
\end{tabular}


Total number of species and percentage recorded in the sugarcane field at Aundipatti

\begin{tabular}{|c|c|c|}
\hline Orders & $\begin{array}{c}\text { Total no. of } \\
\text { species }\end{array}$ & Percentage (\%) \\
\hline Coleoptera & 7 & 23.3 \\
\hline Diptera & 3 & 17.6 \\
\hline Hemiptera & 5 & 29.4 \\
\hline Hymenoptera & 4 & 23.5 \\
\hline Lepidoptera & 5 & 29.4 \\
\hline Odonata & 2 & 11.7 \\
\hline Orthoptera & 4 & 23.5 \\
\hline Total & $\mathbf{3 0}$ & \\
\hline
\end{tabular}

Correlation between monthly population and abiotic factors in sugarcane field at Aundipatti

\begin{tabular}{|c|c|c|}
\hline Orders & Abiotic factors & $\begin{array}{c}\text { Correlation } \\
\text { coefficient } \\
\gamma\end{array}$ \\
\hline Coleoptera & $\begin{array}{l}\text { Max. Temperature } \\
\text { Min. Temperature } \\
\text { Total Rainfall }\end{array}$ & $\begin{array}{r}-0.73 \\
-0.05 \\
-0.26\end{array}$ \\
\hline Diptera & $\begin{array}{l}\text { Max. Temperature } \\
\text { Min. Temperature } \\
\text { Total Rainfall }\end{array}$ & $\begin{array}{l}-0.26 \\
0.17 \\
-0.44\end{array}$ \\
\hline Hemiptera & $\begin{array}{l}\text { Max. Temperature } \\
\text { Min. Temperature } \\
\text { Total Rainfall }\end{array}$ & $\begin{array}{l}-0.01 \\
0.79 \\
0.91\end{array}$ \\
\hline Hymenoptera & $\begin{array}{l}\text { Max. Temperature } \\
\text { Min. Temperature } \\
\text { Total Rainfall }\end{array}$ & $\begin{array}{l}-0.07 \\
0.46 \\
-0.25\end{array}$ \\
\hline Lepidoptera & $\begin{array}{l}\text { Max. Temperature } \\
\text { Min. Temperature } \\
\text { Total Rainfall }\end{array}$ & $\begin{array}{l}-0.25 \\
0.87 \\
0.42\end{array}$ \\
\hline Odonata & $\begin{array}{l}\text { Max. Temperature } \\
\text { Min. Temperature } \\
\text { Total Rainfall }\end{array}$ & $\begin{array}{l}-0.11 \\
-0.56 \\
0.54\end{array}$ \\
\hline Orthoptera & $\begin{array}{l}\text { Max. Temperature } \\
\text { Min. Temperature } \\
\text { Total Rainfall }\end{array}$ & $\begin{array}{l}-0.63 \\
-0.01 \\
-0.47\end{array}$ \\
\hline
\end{tabular}

Monthly population of coleopterans in sugarcane field at Aundipatti

\begin{tabular}{|l|l|l|l|l|l|l|l|l|}
\hline Coleopterans & July & August & September & October & November & December & Total & \% \\
\hline $\begin{array}{l}\text { Melanotus } \\
\text { communis }\end{array}$ & 11 & & & 5 & 20 & 45 & 81 & 23.3 \\
\hline G.bimarginata & & 7 & & & 11 & & 18 & 5.1 \\
\hline $\begin{array}{l}\text { Dermolepida } \\
\text { albohirtusn }\end{array}$ & 40 & & 8 & 9 & & & 57 & 16.4 \\
\hline $\begin{array}{l}\text { Holotrichia } \\
\text { seerata }\end{array}$ & 18 & & & 12 & 20 & 50 & 14.4 \\
\hline $\begin{array}{l}\text { Holotrichia } \\
\text { consanguinea }\end{array}$ & 20 & 6 & & 2 & & 40 & 68 & 19.5 \\
\hline $\begin{array}{l}\text { Anomala } \\
\text { bengalensis }\end{array}$ & & 6 & 4 & & 30 & & 40 & 11.5 \\
\hline Maladera Sp. & 27 & 1 & & 2 & & 3 & 33 & 9.5 \\
\hline \begin{tabular}{l} 
Total \\
\hline
\end{tabular} & 98 & 38 & 12 & 18 & 73 & 108 & 347 & \\
\hline
\end{tabular}


Monthly population of Dipterans in sugarcane field at Aundipatti

\begin{tabular}{|l|l|l|l|l|l|l|l|l|}
\hline Dipterans & July & August & September & October & November & December & Total & $\%$ \\
\hline $\begin{array}{l}\text { Mayetiola destructor } \\
\text { (Say) }\end{array}$ & 123 & 57 & & 160 & 190 & 530 & 38.6 \\
\hline Calliphora sp. & 345 & & 56 & 134 & 18 & 27 & 580 & 42.3 \\
\hline $\begin{array}{l}\text { Musca domestica } \\
\text { (Linnaeus) }\end{array}$ & 95 & 32 & 15 & 16 & & 103 & 261 & 19.0 \\
\hline Total & 440 & 155 & 128 & 150 & 178 & 320 & 1371 & \\
\hline
\end{tabular}

Monthly population of Hemipterans in sugarcane field at Aundipatti

\begin{tabular}{|l|l|l|l|l|l|l|l|l|}
\hline Hemipterans & July & August & September & October & November & December & Total & $\%$ \\
\hline $\begin{array}{c}\text { Ceratovacuna } \\
\text { lanigera } \\
\text { (Zehntner) }\end{array}$ & 16 & 38 & & 2 & & 56 & 33.1 \\
\hline $\begin{array}{l}\text { Aleurolobus } \\
\text { barodensis }\end{array}$ & 25 & 9 & & & 4 & & 25 & 2.9 \\
\hline $\begin{array}{l}\text { Saccharicoccus } \\
\text { sacchari }\end{array}$ & 27 & 6 & 17 & & 3 & & 26 & 15.3 \\
\hline $\begin{array}{l}\text { Melanaspis } \\
\text { glomerata }\end{array}$ & 9 & 8 & & & 5 & & 22 & 13.0 \\
\hline $\begin{array}{l}\text { Metamasias } \\
\text { hemipterous }\end{array}$ & 52 & 48 & 55 & & 14 & & 169 & \\
\hline Total & & & & & & & & \\
\hline
\end{tabular}

Monthly population of Hymenopterans in sugarcane field at Aundipatti

\begin{tabular}{|c|c|c|c|c|c|c|c|c|}
\hline Hymenopterans & July & August & September & October & November & December & Total & $\%$ \\
\hline Corynepherus canescens $L$. & 20 & 7 & 17 & & 3 & & 47 & 23.6 \\
\hline Agrostis capillaries L. & & 73 & & 20 & & 7 & 100 & 50.2 \\
\hline Tetramorium Sp. & 3 & & 8 & & 10 & 2 & 23 & 11.5 \\
\hline O. fragilis & & 12 & 4 & 5 & 3 & 5 & 29 & 14.5 \\
\hline Total & 23 & 92 & 29 & 25 & 16 & 14 & 199 & \\
\hline
\end{tabular}


Monthly population of Lepidopterans in sugarcane field at Aundipatti

\begin{tabular}{|l|l|l|l|l|l|l|l|l|}
\hline Lepidopterans & July & August & September & October & November & December & Total & \% \\
\hline Diatraea saccharalis & 4 & 5 & & 48 & 53 & 45 & 155 & 35.7 \\
\hline Eldana sacharina & & & 13 & & 26 & 21 & 60 & 13.8 \\
\hline Chilo infuscatellus & & 12 & & 8 & 28 & 7 & 55 & 12.6 \\
\hline $\begin{array}{l}\text { Chilo sacchariphagus } \\
\text { indicus }\end{array}$ & & & 10 & & 15 & 50 & 75 & 17.2 \\
\hline $\begin{array}{l}\text { Scirphophaga excerptalis } \\
\text { Total }\end{array}$ & 3 & 19 & 17 & 20 & 30 & 89 & 20.5 \\
\hline
\end{tabular}

Monthly population of Odonata in sugarcane field at Aundipatti

\begin{tabular}{|l|l|l|l|l|l|l|l|l|}
\hline Odonata & July & August & September & October & November & December & Total & $\%$ \\
\hline $\begin{array}{l}\text { Libellula luctosa } \\
\text { Burmeister }\end{array}$ & $\mathbf{2 1}$ & $\mathbf{8}$ & $\mathbf{4 3}$ & $\mathbf{4 1}$ & $\mathbf{4 5}$ & $\mathbf{5 0}$ & $\mathbf{2 0 8}$ & $\mathbf{7 4 . 8}$ \\
\hline Varies & & 5 & 22 & & 26 & 17 & 70 & 25.1 \\
\hline Total & $\mathbf{2 1}$ & $\mathbf{1 3}$ & $\mathbf{6 5}$ & $\mathbf{4 1}$ & $\mathbf{7 1}$ & 67 & $\mathbf{2 7 8}$ & \\
\hline
\end{tabular}

Monthly population of Orthopterans in sugarcane field at Aundipatti

\begin{tabular}{|l|l|l|l|l|l|l|l|l|}
\hline Orthopterans & July & August & September & October & November & December & Total & $\%$ \\
\hline $\begin{array}{l}\text { Melanoplus differentialis } \\
\text { (Thomas) }\end{array}$ & 46 & 5 & 7 & & 9 & 68 & 135 & 39.7 \\
\hline Scudderia sp & & 28 & & 18 & & & & \\
\hline Gryllus sp. & 9 & & 35 & 11 & 15 & 52 & 122 & 35.8 \\
\hline $\begin{array}{l}\text { Scapteriscusborellia } \\
\text { Giglio-Tos }\end{array}$ & 3 & 14 & & & 5 & 15 & 37 & 10.8 \\
\hline Total & 58 & 47 & 42 & 29 & 29 & 135 & 340 & \\
\hline
\end{tabular}

Monthwise insect population of Orthoptera in sugarcane field

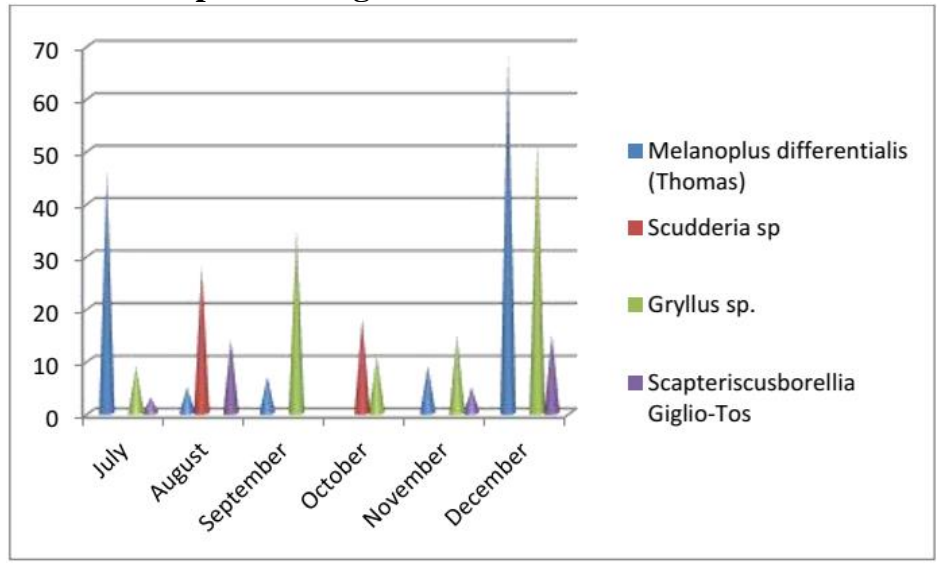


Monthwise inspect population of Odonata in sugarcane field

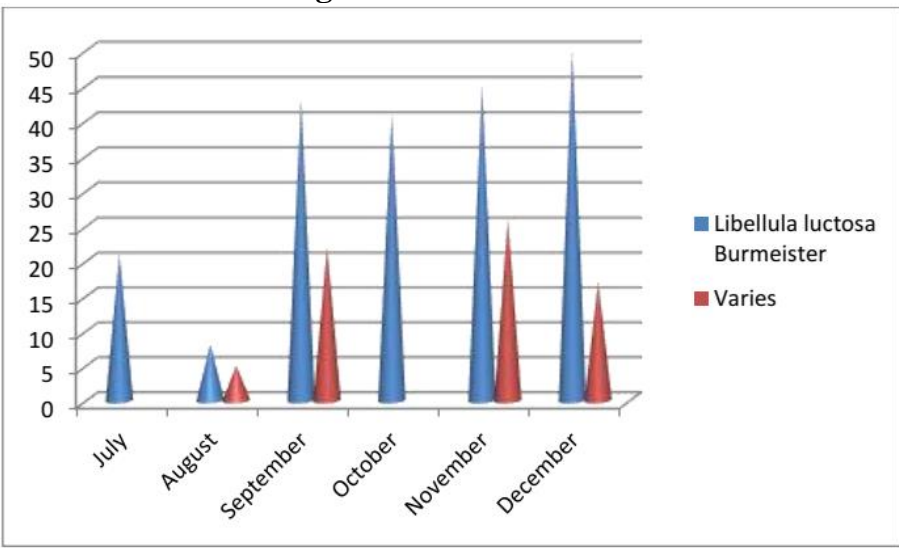

Monthwise insect population of Lepidoptera in sugarcane field

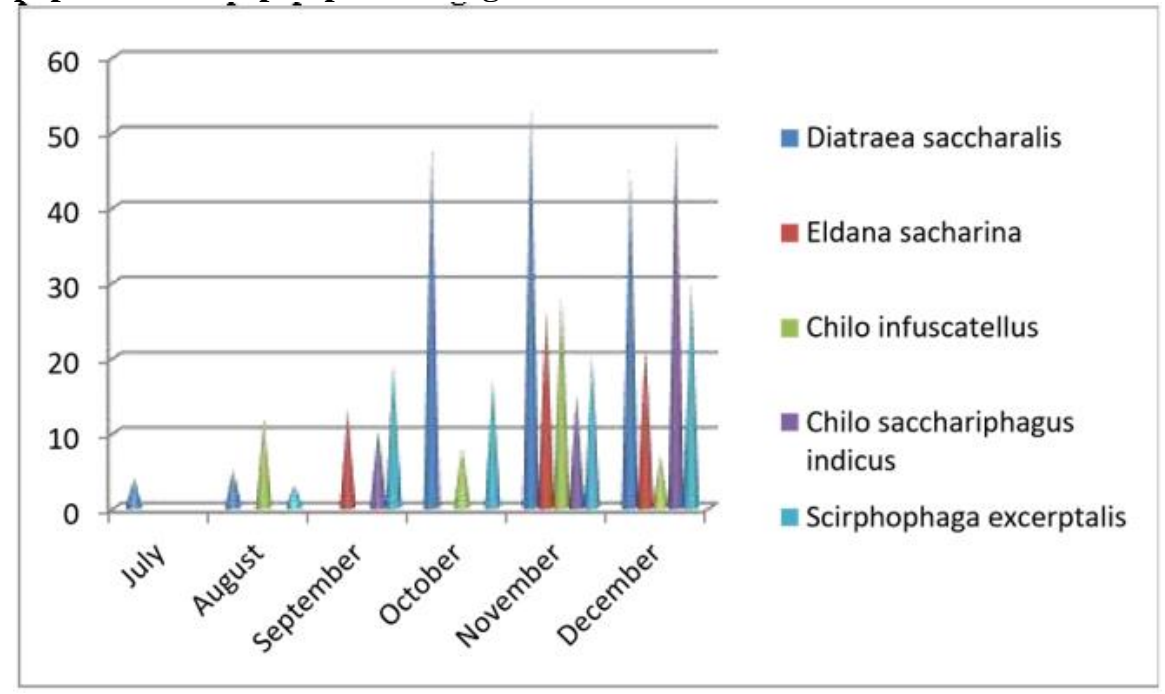

Monthwise insect population of Hymenoptera in sugarcane field

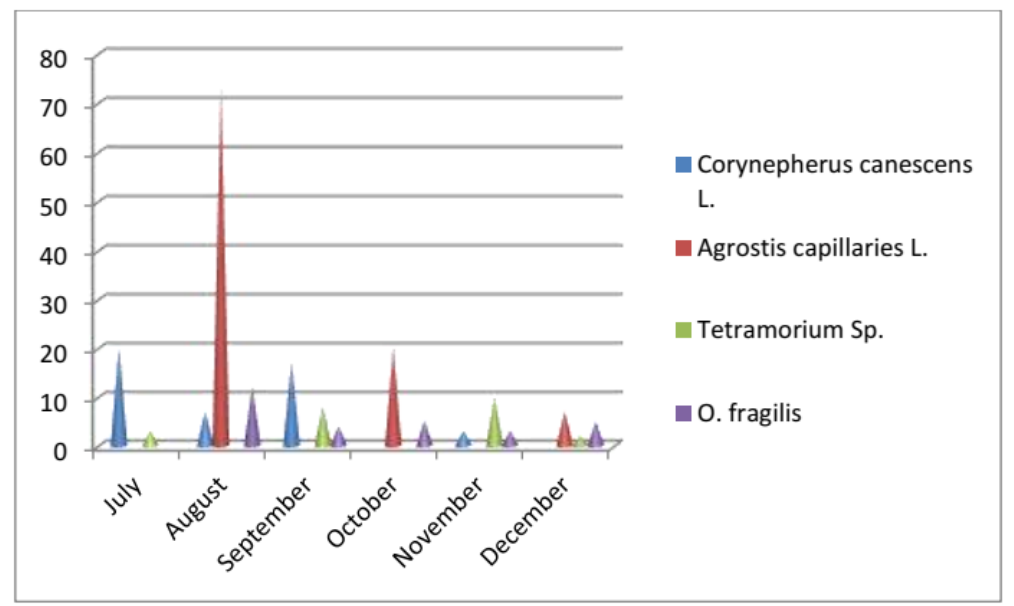


Monthwise insect population of Hemiptera in sugarcane field

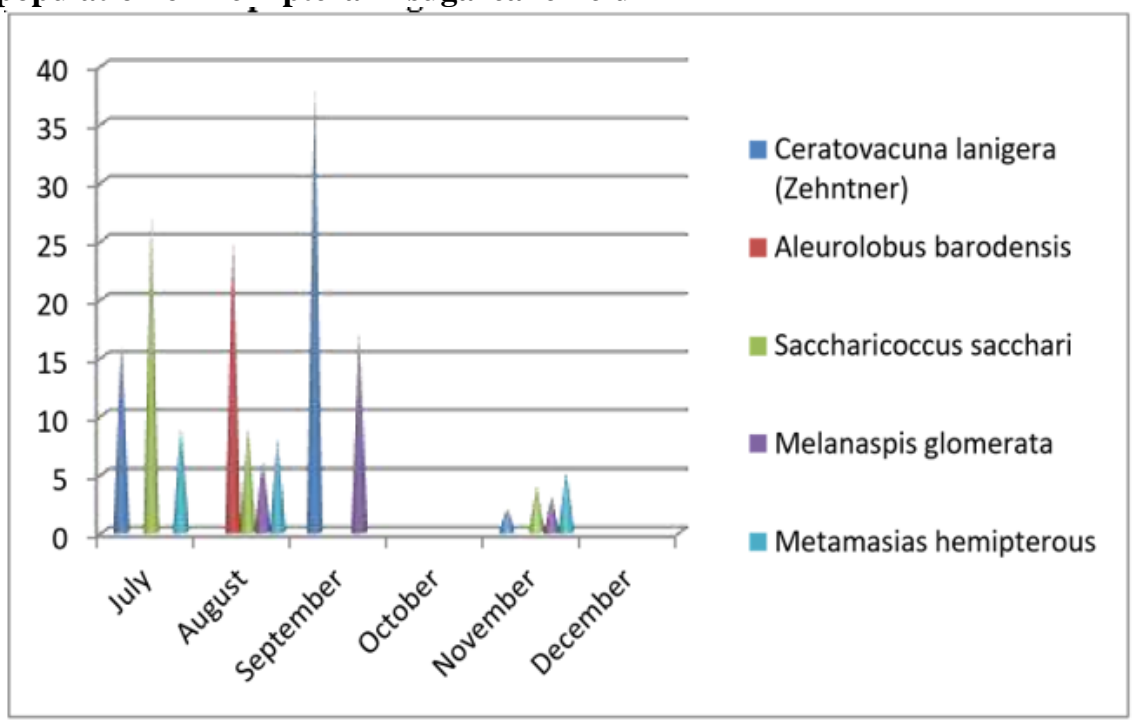

Monthwise insect population of Coleoptera in sugarcane field

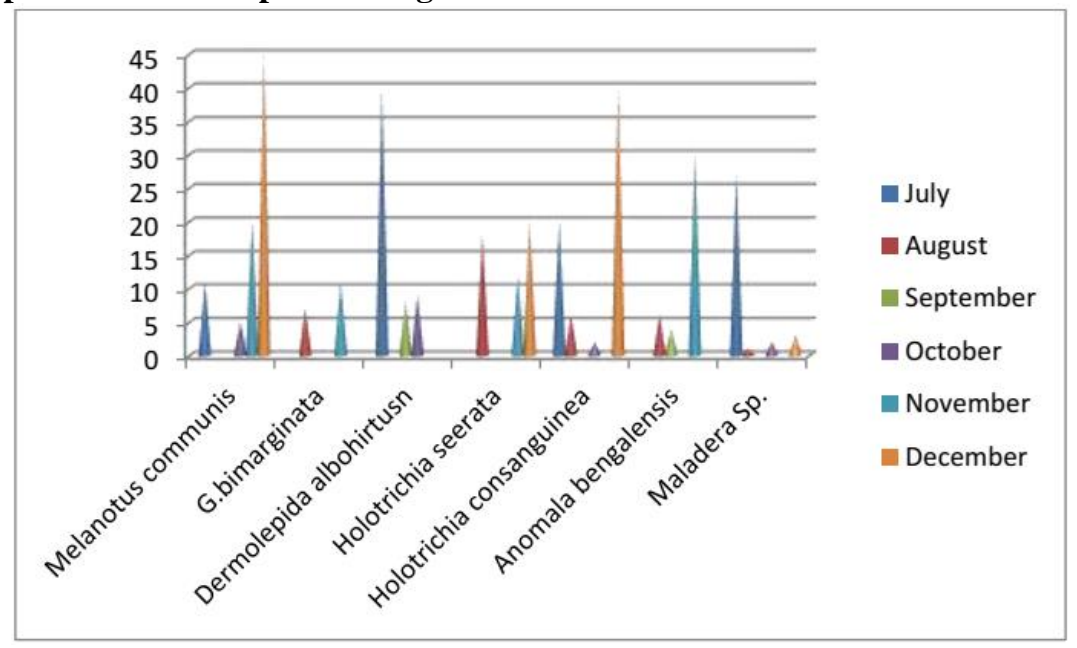

Monthwise insect population of Diptera in sugarcane field

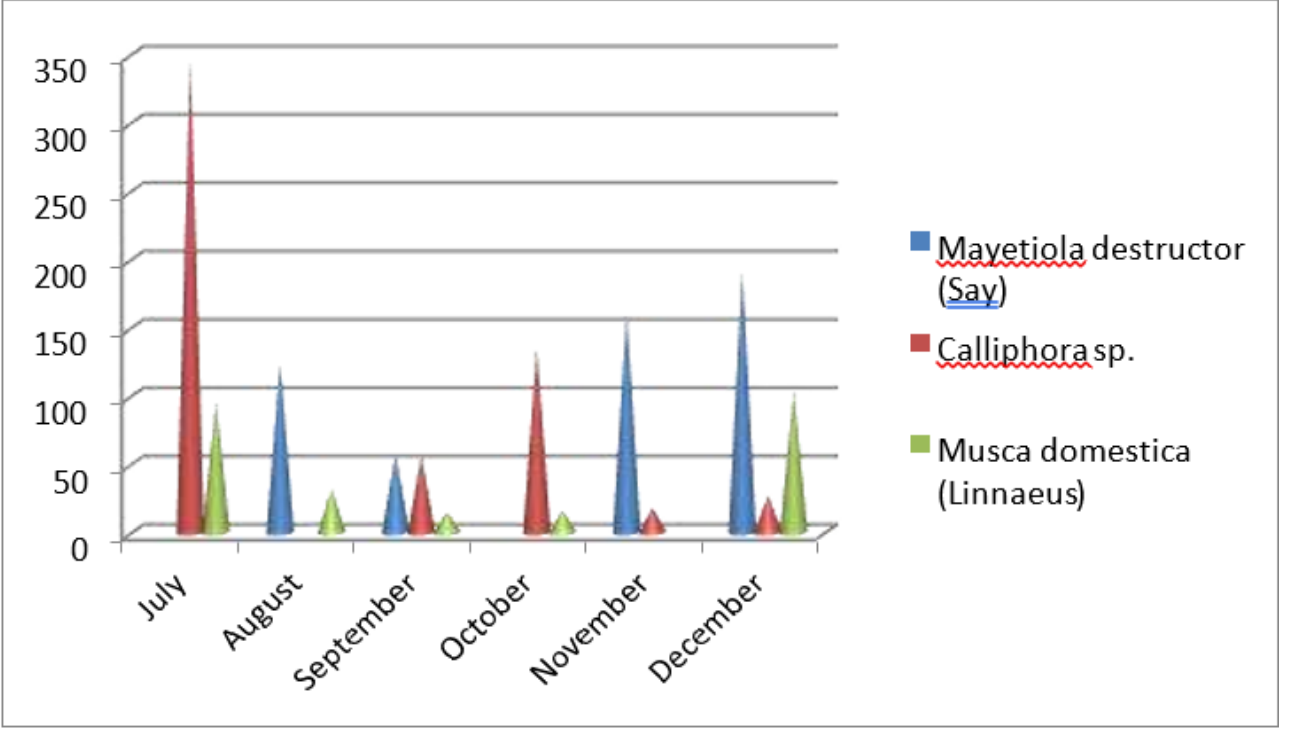

\section{RESULT Coleoptera}

A total of 347 coleopterans belonging to 7 species were recorded in sugarcane field. Melanotus communis population was highly dominant (81). The peak population occurred (108) in December 2011 and dipped to the lowest ebb (12) in September 2011. 


\section{Diptera}

In this sugarcane field a total number of 1371 dipterans belonging to 3 species were recorded, Calliphora sp. was the most abundant species (580). The lowest level (128) observed during September 2011.

\section{Hemiptera}

Five species of Hemipterans observed in this sugarcane field. Ceratovacuna lanigera (Zehntner) were the most abundant (56) Hemipterans. Hemipterans were found only for 4 months with consistent distribution. The population first appeared in July 2011(52), August 2011 (48) and September 2011 (55) then disappear and reappeared in November 2011 (14), thereafter disappeared.

\section{Hymenoptera}

At this sugarcane field, a total of 199 Hymenopterans belonging to 4 species were recorded. Agrostis capillaries $L$. was the most dominant (100) whereas the Tetramorium Sp. was the least (23).

\section{Lepidoptera}

A total number of (434) Lepidopterans belonging to 5 species were observed in the collection made in this field. Diatraea saccharalis were the most dominant (155) Lepidopterans.Initially Lepidopterans appeared with a minimal population (4) in July 2011 and reached a peak (153) in December 2011.

\section{Odonata}

In this sugarcane field a total of 278 Odonata belonging to two species were recorded, Libellula luctosa (Burmeister) was the most abundant (208) and Varies was the least represented (70).

\section{Orothoptera}

Four speacies of Orthopterans were recorded in the sugarcane field. Melanoplus differentialis (Thomas) were the most abundant (135) whereas Scapteriscusborellia Giglio-Tos were the least represented (37). Scudderia sp. occurred only August and October 2011.

\section{DISCUSSION}

The analysis of data in order wise population dynamics of insects revealed the predominance of coleopterans followed by Lepidoptera and Orthoptera. Hemiptera and Hymenoptera species were moderately abundant. Odonata were at the lowest. Peak population of coleopteran, in the sugarcane field were December 2011, Diptera in July 2011, Hemipterans in September 2011 and Odonata in November 2011. Coleopterans with countless adaptations and wide distribution have occupied a dominant position as the largest group in animal kingdom. (Nayar et al. 1990). The study area was dominated by coleopterans in terms of species diversity than all the other orders. The population consistently available in good number during the study period with a peak in December. Higher coleopterans population was found to be existing with rainfall. Most beetles prefer thick vegetation which was available during monsoon season would probably the reason for maximum number for beetles collected most of the wet months. From available literature it was evident that $t$ the coleopteran $\mathrm{s}$ were found to be maximal only during wet months and not during dry months.

The peak Lepidopteron population was noted during November and December 2011. Observations throughout the years have led sugarcane industry consultants, growers and Researchers to suggest that frequent rainfall is an important factor in increasing sugarcane borer infestations. Hensley (1971) documented that weather conditions favorable to rapid growth of the sugarcane plant (warm temperature and abundant rainfall) invariable result in rapid increase in populations of the sugarcane borers. The minimal population was found in July 2011. The maximum Hemipterons population occurred during September 2011 was due to the dominance of Ceratovacuna lanigera (Zehntner). Vats and Handa (1983) reported that the Hemipterons were found to be dominant in summer. It was also true in the case present study that the Hemipterons were found at low level during rainy season.

The peak Hymenopteran population was noted during August 2011 and minimum during December 2011. The peak was mainly due to the dominance of Agrostis capillaries L. Vats and Handa (1983) who reported that the Hymenopterons were found to be dominant during summer season. During summer the ant nest could be heated by the sun, which could be required for the development of ant broods (Nielson 1978) and it was natural that the population was at its peak in summer. The Othopteron population peak in December 2011, comprised of 4 species. Vats and Mittal (1981) observed peak density of Orthopterons in early rainy season in India.

Muralirangan et al (1993) reported that higher temperature with less soil moisture hindered the density of Orhtopteron population.

Diptera is one of the largest order comprising of many insects. The maximal Dipteran population in July, at the middle of the summer season in the study area. Many gall midges are important pests. The mosquitoes were also most abundant. The eggs are laid either on the surface of water or near water (Ambrose 2004). The maximum Odonata population occurred during November 2011. Truman and Rowe (2008) reported the Odonates can be collected from places near water bodies, meadows, wood ands and the hill slides above aquatic habitats. From available literature it was evident that the Odonates were found to be maximal only during wet months and not during dry months. The present study throws on the population dynamics of entomofauna in sugarcane fields. It will help to evolve measures to conserve and proper management of the sugarcane agro ecosystem through future programmes. 


\section{REFERENCES}

[1].Ambrose, D.P (2004). The Insects: structure, function and biodiversity. Ludhiana, India: Kalyani Publishers. PP. 821.

[2].Ambrose, D.P. and D. Livingstone. (1989). Population dynamics of Assassin bugs from Peninsular India (Insecta: Heteroptera: Reduviidae. J. Bombay Nat.Hist.Soc.,86:388-395.

[3].Anonymous (2006). Economic survey. Govt. of Pak. Finance division. Economic Advisory wing, Islamabad, pp. 14.

[4].Chu C. C., Pinter P. J., Henneberry T. J., Umeda K., Natwick E.T., 2000.- Use of CC traps with different trap base colors for silverleaf whiteflies (Homoptera: Aleyrodidae) thrips (Thysanoptera: Thripidae) and leafhoppers (Homoptera: Cicadellidae).- Journal of Economic Entomology, 93: 1329-1337.

[5].David, H and V. Nandagopal (1988). Pests of sugarcane distribution, symptomatology of attack and identification. Sugarcane Entomology in India, (Ed. David, H., Easwarmoorthy, S. and Jayanthi, R.), Sugarcane Breeding Institute (ICAR), Coimbatore Publication, pp. 1-29.

[6].Hansely, S.D. (1971). Management of sugarcane borer population in Louisiana, a decade of change. Entomophaga 16: 133-146.

[7].Iqbal M, Haq Z, Jamil Y, Ahmad MR (2012). Magnetic treatment on growth and chlorophyll sativum L.). Int. J. Agrophysics. (Accepted).

[8].Kersting U., Baspinar H., Uygun N., Satar S., 1997.- Comparison of two sampling methods for leafhoppers (Homoptera: Cicadellidae) associated with sesame in the east Mediterranean region of Turkey. - Journal of Pest Science, 70: 131-135.

[9].Muralirangan, M.C, Suresh, P and P.P. Dhang (1993). Observations on the grasshopper species diversity, density and distributional pattern in peninsular India. Can. Entomol. 112(3,4):201-210.

[10]. Nader Sallam (2011) Review of current knowledge on the population dynamics of Dermolepida albohirtum (Waterhouse) (Coleoptera: Scarabaeidae). aAustralian Journal of Entomology,BSES Limited, PO 122, Gordonvale, Qld 4865, Australia.50, 300-308.

[11]. Nayar, K.K., T.N. Ananthakrishnan and B.V.David (1990). General and applied entomology.

[12]. Tata Mc Graw-Hill Publishing company Ltd. New Delhi. PP.589.

[13]. Neilsen. (1978). The ant fauna (Hymenoptera: Formicidae) in Northern and interior Alaska. Entmol. News, 98 (2): 74-87.

[14]. Raja K. M., Arivudainambi S., (2004). Efficacy of sticky traps against bhendi leaf hopper, Amrasca biguttula biguttula Ishida. - Insect Environment, 10: 32-32.

[15]. Ramamurthy V. V., Akhtar M. S., Patankar N. V., Menon P., Kumar R., Singh S. K., Ayri S., Parveen S., Mittal V., (2010). Efficiency of different light source in light traps in monitoring insect diversity. - Munis Entomology and Zoology, 5(1): 109-114.

[16]. Vats, L. K. and Mittal. (1983). Insect population density in tropical deciduous forest stand. Proc. of IV. All India symp. Environ. Biol., (Ed) A.K. Dattagupta and R.P. Malbyva.

[17]. Verma, R., S.M. Vaishampayan and R.R. Rawat. (1982). Influence of weather factors on the light trap catch of Gram podoborer, Heliothis armigera (Huner) moths. Indian J. Ent., 44 (3): 213-218. 